\title{
The fabric of resilience among the elderly and the reinvention of the self despite the difficulties faced
}

Daniel Rocha Silveira'

Karla Cristina Giacomin ${ }^{2}$

Rosângela Correa Dias ${ }^{3}$ Josélia Oliveira Araújo Firmo,2

Abstract

Objective: To seek an understanding of how frail elderly persons construct resilience. Method: The "signs, meanings and actions" model was used. The population was randomly selected among elderly persons classified as robust or pre-frail in the FIBRA-study, Belo Horizonte, Minas Gerais, Brazil. Thirteen elderly persons (aged 69 to 86) were interviewed. Results: a) the construction of bonds - a healthy relationship with spouses, sons, daughters, grandchildren and great-grandchildren brings meaning to and sustains life and contributes to its organization; b) the reinvention of oneself - when suffering trauma, elderly people seek paths that can give sense to life, even if difficult memories persist; c) religiosity: catholic, evangelical or spiritualist experiences strengthen; cures, protections and so-called miracles are valued, and the religious community represents a space for belonging. Conclusion: Resilience is constructed through the bonds between the elderly person and those close to them, and in the search for solutions, including through the religious experience.

\footnotetext{
Fundação Oswaldo Cruz, Instituto René Rachou, Programa de Pós-graduação em Saúde Coletiva. Belo Horizonte, Minas Gerais, Brasil.

2 Fundação Oswaldo Cruz, Instituto René Rachou, Núcleo de Estudos em Saúde Pública e Envelhecimento. Belo Horizonte, Minas Gerais, Brasil.

3 Universidade Federal de Minas Gerais, Escola de Educação Física, Departamento de Fisioterapia e Terapia Ocupacional. Belo Horizonte, Minas Gerais, Brasil.
}

Research funding: Minas Gerais Research Support Foundation (FAPEMIG) (APQ-00703-17), National Council for Scientific and Technological Development (CNPq) (research grant 303372/2014-1)

Correspondence

Josélia Oliveira Araújo Firmo

firmoj@cpqrr.fiocruz.br, firmoj@gmail.com
Keywords: Elderly. Psychological Resilience. Frail Elderly. 


\section{INTRODUCTION}

The term "resilience" conjures of the image of a leap forward, falling and getting back up again, flexibility, adaptation, resistance, overcoming, strengthening and recovery ${ }^{1}$. Individuals, although struck down by trauma, rebuild and resist. They suffer, but despite everything, maintain hope ${ }^{2}$.

Human resilience refers to the strategies used to remove the barriers that limit us ${ }^{3}$. Everyone, at some point, must learn to endure and do the best they can: to step outside themselves and look within to recognize their inner resistance, compassion, courage and humanity, in order to support or help make the difficult paths of others bearable ${ }^{4}$.

In old age, resilience forms part of coping strategies ${ }^{5}$. Literature describes how the development of these strategies ${ }^{6}$ is important for the elderly person to assign meanings to the difficult events of life, transforming suffering into meaningful experiences. Frank $1^{7}$ states that finding a meaning for life provides the individual with great strength: a person can be deprived of everything but the ultimate freedom to take an alternative approach to situations. Goldemberg ${ }^{8}$ describes the results of interviews with elderly people from the southern part of Rio de Janeiro, who state that a beautiful old age can be built through a life plan.

The authors of a review article describe the path that the concept of resilience must take ${ }^{9}$, with three different generations of researchers addressing the theme. The first focuses on children and young people subjected to situations of extreme poverty and trauma yet who did not demonstrate problems with psychological or social adaptation in the future. The second phase went beyond personal qualities and processes of adaptability and asked about the psychosocial conditions and social and cultural processes that favor or hinder the response of the subject to adversity. Finally, the third phase recognized that resilience contains an element of social construction, a sharing of life with others. Although individuals can move forward through their own efforts, resilience is strengthened through the involvement of others. In this sense, resilience can favor the promotion of integrated health and the recovery of the human and social fabric, allowing the possibility of a dignified existence in unfavorable contexts. The question that arises, therefore, is how resilience occurs in a context of markedly unequal population aging, such as in Brazil?

One of the consequences of population aging is the increased number of frail elderly people? ${ }^{9}$. Frailty can be defined by objective criteria, such as those proposed by Fried et al. ${ }^{10}$, but also refers to the human condition of finitude and vulnerability, including the contradictions present in relationships ${ }^{11}$. A review on Brazilian academic production on the resilience of the elderly between 2000 to 2015 found low productivity on this theme ${ }^{6}$. Among elderly persons from the city of Belo Horizonte who participated in a multicentric study on frailty (the FIBRA Network), Vieira et al. ${ }^{12}$ found a prevalence of frailty of $8.7 \%$. The question then arises: how do these elderly persons create and/or seek resources to deal with their adversities? This study aims to seek an understanding, from the perspective of elderly persons who are becoming frail, about how they develop resilience to the troubles they perceive in their life.

\section{METHOD}

The sample of the present study was selected from the participants of a study that investigated the profile, associated factors and prevalence of frailty among the elderly, based on the criteria of Fried et al..$^{10}$ - the Study Network on Frailty Among The Brazilian Elderly (FIBRA Network). This was a cross-sectional, multidisciplinary and multicentered study, based on five hubs (Universidade Federal de Minas Gerais, Universidade de Campinas, Universidade de São Paulo-Ribeirão Preto and the Universidade do Estado do Rio de Janeiro). For the present study, elderly persons classified as robust or pre-frail in 2009 were randomly selected from the database of the Belo Horizonte hub ${ }^{13}$. The increased morbidity and mortality observed in the frail group made their eligibility for the study impractical.

The interviews were conducted between January and August 2016 and included people of different genders, ages, functional status and place of residence. After being informed about the study and signing a Free and Informed Consent Form, the selected individuals were interviewed in person at their homes using a semi-structured script. The sample size was regulated by the saturation criterion ${ }^{14}$. 
Two generative questions were applied: a) Is anything troubling you now? and b) How do you deal with what is troubling you? These questions were used to understand perceptions about the process of becoming frail and the possible coping strategies developed.

Data collection and analysis were based on the "Signs, meanings and actions" model, ${ }^{15}$ which allows an understanding of the significant elements of how the universe of health problems of each community is constructed, highlighting a particular symptom and encouraging an explanation and certain types of reactions and actions. This model departs from the pragmatic approach and instead functions at a semantic level. In it, the concrete behaviors of individuals can be identified along with the conceptual logics linked to such actions, as well as the different factors that influence them ${ }^{15}$.

All the interviews were recorded, transcribed and exhaustively and closely read, to identify the analytical categories and their interaction between them, as well as their articulation with the current sociocultural context.

The analysis of the data included a descriptive organization, a panoramic reading, the identification of categories, an in-depth reading, modifications of categories; and a deeper theoretical investigation of relationships with other findings and interpretations present in literature and in secondary data.

To preserve anonymity, respondents were identified by order of interview, gender and age in years.

This study is part of the Frailty among the elderly: perceptions, cultural mediation, coping and care, approved by the Ethics Research Committee of the René Rachou da Fundação Oswaldo Cruz Research Center (Fiocruz) (CAE: 49173415.8.0000.5091).

\section{RESULTS AND DISCUSSION}

A total of thirteen elderly individuals aged 69-86 years (five men and eight women) were interviewed.

During the analysis the term "frailty" as defined in biomedical knowledge was not used by the interviewees. The perception of the process of becoming frail appears linked to the aging revealed in the suffering that reflects the life history, illnesses and other current problems of the elderly, such as a lack of financial resources and urban security. The terms "my age" and "we can't do things like we used to" refer both to the process of frailty linked to biological aging and to a broader existential sense of the term.

To deal with these frustrations, three nuclei of significance emerged on aspects of the fabric of resilience: the construction of bonds, reinventing oneself, and religiosity.

\section{The construction of bonds}

This category describes the different relationships that sustain resilience among frail elderly people. One woman who had taken care of her bedridden husband for more than two years, with limited financial resources, attributed the success of their 61 years of marriage to faithfulness, and repeated maxims like mantras, as they provided them with sustenance to deal with the life ahead: "That's the way life is: one day you're laughing, and one day you're crying. That's what the life of a couple is like. One day you're laughing, and the next you're crying." (I1, F, 83).

One participant who lived with his wife and was being treated for cancer (leukemia) explained: "On Sunday they (their grandchildren) come here and it turns into a party. Two of them are always here, so we take them to school. We take them there and pick them up afterwards. That's life." (I4, M, 69).

An elderly couple displayed affection, consideration, partnership and complicity in their gestures and speeches. The husband explained:

"Over time we realize there are some things we can no longer do the way we used to. We need to be more cautious, more careful ... So we try to do them, but without ... getting frustrated. We think, well we're at that age, but the goal is to keep going as long as we can. If you work at it, I think you can extend it a little longer, in terms of what you want to do, you can live a little more peacefully with the family. Helping people calmly, the ones we need to help ... It's about talking, (...) not fighting for silly reasons" (I7, M, 78). 
The same interviewee said the couple adopts an attitude of prevention:

"I think they (others from the same age group) stop too early. They stop going for walks before they have to, and don't take care of their diet (...). We try and prevent things ... by taking a walk, or going to the doctor. (...) We do everything on the National Health Service, and we're doing well..." (I7, M, 78).

One elderly woman tried to understand the behavior of her grandchildren: "There are some things we are practically obliged to accept, and we can't get annoyed. [Laughs] ... they always come here for support." (I7, F, 73).

The presence of grandchildren brings pleasure and responsibility so that the elderly renew themselves, teaching and learning with the younger generation. This contributes to their satisfaction and feeling of belonging, which strengthens resilience.

One interviewee explained how to cultivate family harmony by avoiding conflicts and concerns:

"My husband and I live alone, as our three children are married. (...) They don't cause us problems. We don't think we create problems for them either. (...) I think you need to have ... patience, to coexist together ... try and avoid things that are annoying, not suffer by anticipating things." (I9, F, 74).

One couple displayed a lack of affection through a tense and aggressive atmosphere. The wife, although she spoke about care and religiosity, externally, verbally and nonverbally exhibited resentment about dealing with her physically incapacitated husband. She says:

"I feel sad when I look at my husband. (...) my life was supposed to be more than this, physically healthier, but I stopped doing my physical exercise, I stopped going out, I stopped dancing, I stopped everything - because of my husband.” (I10, F, 72).

Another respondent, whose husband has Alzheimer's disease, said that in order to reduce her husband's suffering and irritation, she tried to minimize memory loss by making him feel comfortable. She sought and found strength in the happy memories of when they were dating. These findings agree with those of $\mathrm{Frank}^{7}$, for whom the positive moments lived become part of a body of achievements: reminiscing about them provides comfort and strength in the search for the meaning for life, despite current suffering.

The presence of friends and a support network is very important, as this elderly woman explained:

"I have a great friend, who he (the sick husband)
likes very much. She comes over and spends time
with him so I can go out, and he sings the carnival
songs, remembering all the old songs (...). It's not
as hard for us nowadays. (...) I have organized
my life, I have a taxi driver that takes him ... to
physiotherapy ... he stays with him there, it's really
good, he checks that he is doing it right. Meanwhile
I get some time alone - because I need to be alone
once in a while - I can go out a little." (I7, F, 86).

Social support is fundamental to the fabric of resilience. All the interviewees who were married, lived with their spouses, and described a good relationship with their partner demonstrated the fact that such a bond gives meaning to and sustains life, representing an organizing factor of comfort and well-being. These include affective experiences with friends and the support of children, grandchildren and great-grandchildren.

These findings agree with the reflections of Karin et al. ${ }^{16}$, for whom, in the face of adversity, secure affective bonds provide support and a framework for summoning help, and are fertile ground for creating meaning that sustains life. Life can bring lasting pain which arises in unfavorable contexts, such as urban infrastructure, financial difficulties and chronic and/ or progressive illnesses. Surviving each day becomes arduous, and affectionate bonding facilitates and encourages comfort and strength, motivating the individual to look for strategies that can create joy ${ }^{17-19}$.

When social support is not present, the individual must reinvent themselves, as can be seen in the next category. 


\section{Reinventing oneself}

The narratives demonstrate the experience of reinventing oneself with and despite adversities. One participant reported suffering that began in childhood, due to having suffered a congenital disease (toxoplasmosis) and being taken to live with another, evangelical family, because of his mother's disease (tuberculosis), following medical orders. When aged 22, he moved to the capital, lived in a rooming house, and suffered financial and food deprivation. He said that he developed, throughout his life, a dependent personality:

"I have a very serious problem, because I was raised away from my family, and in a home. (...) I have become a very dependent person. I started to develop my independence after I turned 40. (...) I went for a civil service job (...) and I passed. After that, after the age of 40, I felt freer. I said 'I can't carry on like this, being dependent all my life, I have to do something'. That's when I woke up" (I12, M, 74).

Increased self-awareness has raised his awareness of his life process and brought a number of benefits. On the other hand, the interviewee acknowledged that if "I get worried about things, I suffer health problems." He said he currently had a healthy lifestyle with a balanced diet, health care through the National Health Service, and that he went for walks and was being treated for various medical problems: depression, prostate illness, hypertension and insomnia.

Another interviewee had a nervous breakdown when she was 25 and was thereafter labeled "crazy" and stigmatized:

"The prejudice is enormous, the stigma is enormous, everyone calls you 'Crazy'. (...)I suffered a lot because of that, and I've been working with therapists and especially religious people." (I8, F, 69).

When asked about how she dealt with this, she explained that financial resources help a lot: "It's because you can pay a therapist, (...), pay a lawyer ... buy the medicine ..."
Other interviewees experienced financial difficulties, as in this extract:

\begin{abstract}
"I buy what I can, what I can afford, but I have debts. The bills are late, the water bill is late. But it's not just me. I heard on the radio that practically $64 \%$ of people are in this situation. So I don't spend more than I can." (I11, F, 74).
\end{abstract}

In the present study, experiences in childhood, youth, and old age, with or without financial resources, affected the lives of these individuals despite the fact they did not choose them. These frustrations and adversities have become the ingredients for a (re) construction of the self, as far as possible.

The perception of the interviewees about how they deal with what makes them frail relates to the experience of Cyrulnik ${ }^{2}$ : resilience is metamorphosing, a re-creation of oneself. Metaphorically, in the fabric of resilience, when suffering a trauma, one part of the person becomes necrotic, while another seeks, through the strength that despair can bring, ways that give meaning to life, reaching out towards living and building. From this point on, a new philosophy emerges, a vision of one's own that gives meaning to the trauma, even if the memories of the suffering persist, such as in the form of flashbacks. The traumatized person seeks all that they can enable them to live with pleasure and meaning ${ }^{2}$.

\section{Religiosity}

The presence of religiosity among the interviewees represented a pillar in the fabric of resilience, whether through contact with Catholicism, the evangelical church, or Kardecist spiritualism.

One Spiritist interviewed said:

"(Religion) is something else that makes it much
easier for us. I am a medium, I participate in a
Spiritist group. He also works as a medium (...). I
read a lot ... And we both talk about it". (I7, F, 73).

For her husband, religion allows one to deal more peacefully with death and life: "We are not afraid of the future or of dying". (I71, M, 78). 
When faced with adversity, the expression of relief through spiritual healing, faith and contentment in the face of spirituality, represented a great facilitator of resilience for this elderly woman:

"I had a serious heart problem, I was hospitalized. (...) I felt very low, and so on, but ... we don't go before we're called. (...) I underwent spiritual treatment, spiritual surgery, you know? And the results were excellent. (...) When I went back to the cardiologist, he said: 'You have an incredible physiognomy, you've improved so much, what happened?" (I11, F, 74).

With her income, she helps her grandchildren and children, including her unemployed daughter, as well as a brother with mental problems, who lives with her and brought 16 street dogs, which give off a strong odor of urine and feces, into the house.

For one evangelical man, who studied theology, religion brings "the guarantee of a future life, beyond this earth (...). This belief is vital for life to have meaning" (I12, M, 74).

Among the elderly Catholics interviewed, one elderly man commented that he goes to Mass occasionally, but prays every day, asking for: "Safety, health. Illumination of the lives of all his children, both the older and the younger ones". (I4, M, 69). He recognizes the importance of his father's teachings, the values he was taught, which he made a point of passing on to his children: "Work and honesty, and respect for others. So, today, they are all on the right track." (I4, M, 69).

One elderly woman (I1, F, 83) attributed miracles such as the identification of a painless gastric tumor to her devotion to St. Lazarus. The early detection of her condition meant it could be operated on and she subsequently regained her health. When faced with greater pain - the death of her son, which resulted in her voice breaking up during the interview - she also sought solace in faith.

Regardless of the faith professed, the interviewees sought meanings to make sense of life in their religiosity. In religious experience, the individual is guided by the voice of transcendence and the moral conscience, which provides answers to the questions that arise in everyday situations ${ }^{20}$.
A qualitative study on the perception of the elderly about functional incapacity, carried out in Bambuí (Minas Gerais), demonstrated that religiosity works as a form of emotional regulation, and provides the experience of acceptance by an Other, a God that keeps one company, fulfills one, brings peace, and allows the individual to endure the vicissitudes of life more calmly ${ }^{21}$. Our interviewees in Belo Horizonte (Minas Gerais), construct solutions to their suffering and tend to set aside the acceptance that religion provides, only applying it in situations which truly cannot be changed.

As such, religiosity serves as a supportive medium for accepting what cannot be changed and living with it, but/and at the same time actively striving to change what is possible, working towards the solution of problems and the construction of happiness, through a belief in cures, protections, miracles.

The religious community has been valued as a space of belonging, coexistence and well-being, as it allows a sense of connection and brings meaning to life. ${ }^{16}$ The individual discovers, through faith, the chance to be accepted in this or another life(s). This certainty and the confidence that is constructed allow strategies to take an active attitude towards reconnecting (the word stems from the Latin "ligare", meaning to join or link) with the world.

The responses of the elderly interviewed in this research are consistent with the research of $\mathrm{Job}^{22}$, which focuses on the resilience of thirty elderly Jewish people living in São Paulo, survivors of Nazism, and the research by Molton and Yorston ${ }^{23}$ whose participants emphasized that for them, autonomy meant the ability to exert choices, but that this often required negotiation with and assistance from others. Both considered the support of secure bonds, faith and coping skills to be essential factors. Job ${ }^{22}$ pointed out that the survivors found meanings of creation and freedom for their lives. Congruent meanings were found among the elderly in Sweden interviewed by Ebrahimi et al. ${ }^{24}$, who identified the following factors as contributing to resilience in old age: reinforcing a positive outlook; the good humor and the willingness to carry on and continue living; remaining in family surroundings; having good health and the ability to manage daily activities; keeping busy and engaged in useful activities, and not feeling like a burden to others. Social interaction validated a sense of connection 
with others, including acknowledging that there was someone in their lives who cared about them: the elderly Swedish people recognized, as a principle for good health, the need to feel capable, to have control over their body and their psychosocial context.

The construction of resilience allows us to resume/construct our development, to be affected by situations in a new way, to learn through experiences that restore our vital force, and requires the participation of another (who encourages the well-being and active lifestyle of the individual ${ }^{17}$.

It should be stated that resilience is not a search for perfection or complete joy. Nor is it a capacity, a set of attributes that allows one to overcome obstacles and become more resilient, happy and productive. It does include, however, a reflexivity regarding social contradictions and attitudes toward sociopolitical changes ${ }^{24}$ which can generate suffering.

Among the limitations of the present study is the impossibility of interviewing elderly people who were very frail/incapacitated, which prevents us from understanding the strategies of resilience used by those individuals in such conditions. Another is the possibility that frailty manifests itself in situations that could not be captured in the interviews. It was sought to minimize this concern through careful observation throughout the entire process of data collection and analysis.

Adversities have an impact through the inner representation that each person constructs of them, which is based on the way in which their narrative is received in the family and social context. History is not a destiny but an opening. In old age, resilience is maintained through the use of various coping strategies, based on personal, social and spiritual resources ${ }^{5,23-25}$. Aging, too, allows one to say yes to life, despite everything?.

\section{CONCLUSION}

The elderly persons interviewed in the present study dealt with the process of becoming frail as a natural consequence of aging and, when faced with the perceived troubles of their lives, build resilience from the resources they have, such as socio-family relationships and religion. Understanding how the elderly deal with frailty can help professionals, families and administrators involved in elderly care develop strategies to raise awareness about creative and healthy ways to care for and promote quality of life; by developing policies aimed at improving the quality of life of the aging population that is more focused on health, autonomy and potential than on their diseases, losses and limits.

In old age, we can see resilience in the affective fabric between the suffering elderly person and their surroundings. In this movement of seeking strategies to deal with suffering, the narratives highlighted the importance of affectionate bonds for all respondents, such as support and a suitable environment to develop strategies to deal with suffering and motivation for life. The possibility of being loved and faith allow us to resume our development and continue to reinvent ourselves, despite everything ...

\section{REFERENCES}

1. Brandão JM, Mahfoud M, Giardonoli-Nascimento I. Da invulnerabilidade à resiliência: percurso histórico e atualidade do conceito. In Ribeiro W, Romero E, organizadores. Vulnerabilidade humana e conflitos sociais. São José dos Campos: Della Bídia; 2009. p. 189-204.

2. Cyrulnik B. La maravilla del dolor: el sentido de la resiliencia. Buenos Aires: Granica Editora; 2001.

3. Malik K. Sustaining human progress: reducing vulnerabilities and building resilience. New York: United Nations Development Program; 2014. (Human Development Report 2014).
4. Kleinman A. The art of medicine: how we endure. Lancet. 2014;383:119-20.

5. Fontes AP, Neri AL Resiliência e velhice: revisão de literatura. Ciênc Saúde Colet. 2015;20(5):1475-95.

6. Garces SBB, Krug MRO, Hansen D, Brunelli AV, Costa FTL, Rosa CB, et al. Avaliação da resiliência do cuidador de idosos com Alzheimer. Rev Bras Geriatr Gerontol. 2012;15(2):335-52.

7. Frankl VE. Em busca de sentido: um psicólogo no campo de concentração. Petrópolis: Vozes; 2015. 
8. Goldenberg M. A bela velhice. Rio de Janeiro: Record; 2013.

9. Granados-Ospina LF, Alvarado-Salgado SV, Carmona-Parra J. El caminho de la resiliência: del sujeto individual al sujeto politico. Magis, Rev Int Invest Educ. 2017;10(20):49-68.

10. Fried LP, Tangen CM, Walston J, Newman AB, Hirsch C, Gottdiener J, et al. Frailty in older adults: evidence for a phenotype. J Gerontol Ser A Biol Sci Med Sci. 2001;56(3):146-56.

11. Brasil. Portaria n ${ }^{\circ}$ 2528, de 19 de outubro de 2006. Aprova a Política Nacional de Saúde da Pessoa Idosa. 2006. Saúde Legis.

12. Vieira RA, Guerra RO, Giacomin KC, Vasconcelos KSS, Andrade ACS, Pereira LSM, et al. Prevalência de fragilidade e fatores associados em idosos comunitários de Belo Horizonte, Minas Gerais, Brasil: dados do Estudo FIBRA. Cad Saúde Pública. 2013;29(8):1631-43.

13. Faria GS, Ribeiro TMDS, Vieira RA, Silva SLAD, Dias RC. Transition between frailty levels in elderly persons from Belo Horizonte, Minas Gerais, Brazil. Rev Bras Geriatr Gerontol. 2016;19(2):335-41.

14. Fontanella BJB, Luchesi BM, Saidel MGB, Ricas J, Turato ER, Melo DG. Amostragem em pesquisas qualitativas: proposta de procedimentos para constatar saturação teórica. Cad Saúde Pública. 2011;27(2):389-94.

15. Corin E, Uchôa E, Bibeau G, Kouma-Re B. Articulation et variatons des systèmes de signes, de sens et d'actions. Psychopathol Afr. 1992;24:183-204.

16. Joling KJ, Windle G, Dröes RM, Huisman M, Hertogh CMPM, Woods RT. What are the essential features of resilience for informal caregivers of people living with dementia?: A Delphi consensus examination. Aging Ment Health. 2017;21(5):509-17.
17. Cyrulnik B, Cabral S. Resiliência: como tirar leite de pedra. São Paulo: Casa do Psicólogo; 2015.

18. Ungar M. The social ecology of resilience: Addressing contextual and cultural ambiguity of a nascent construct. Am J Orthopsychiatr. 2011;81(1):1-17.

19. Porter KE, Brennan-Ing M, Burr JA, Dugan E, Karpiak SE. Stigma and psychological well-being among older adults with HIV: The impact of spirituality and integrative health approaches. Gerontologist. 2015;57(2):219-28.

20. Coelho Júnior AG, Mahfoud M. As dimensões espiritual e religiosa da experiência humana: distinções e inter-relações na obra de Viktor Frankl. Psicol USP. 2001;12(2):95-103.

21. Santos WJ, Giacomin KC, Pereira JK, Firmo JOA. Enfrentamento da incapacidade funcional por idosos por meio de crenças religiosas. Ciênc Saúde Colet. 2013;18(8):2319-28.

22. Job JRPP. A escritura da resiliência: testemunhas do holocausto e a memória da vida [tese]. São Paulo: Pontifícia Universidade Católica de São Paulo; 2000.

23. Molton IR, Yorkston KM. Growing older with a physical disability: A special application of the successful aging paradigm. J Gerontol Ser B Psychol Sci Soc Sci. 2017;72(2):290-9.

24. Ebrahimi Z, Wilhelmson K, Eklund K, Moore CD, Jakobsson A. Health despite frailty: Exploring influences on frail older adults' experiences of health. Geriatr Nurs. 2013;34(4):289-94.

25. Gijzel SMW, Van de Leemput IA, Scheffer M, Roppolo M, Olde Rikkert MGM, Melis RJF. Dynamical resilience indicators in time series of self-rated health correspond to frailty levels in older adults. J Gerontol Ser A Biol Sci Med Sci. 2017;72(7):991-6. 